Revista Eletrônica de Direito Processual - REDP.

Rio de Janeiro. Ano 13. Volume 20. Número 1. Janeiro a Abril de 2019

Periódico Quadrimestral da Pós-Graduação Stricto Sensu em Direito Processual da UERJ

Patrono: José Carlos Barbosa Moreira (in mem.). ISSN 1982-7636. pp. 362-383

www.redp.uerj.br

\title{
TAX PLANNING IN BRAZIL: LEGAL REASONING AND CONSTITUTIONAL PROCESS IN BRAZILIAN SUPREME COURT ${ }^{1}$
}

\section{PLANEJAMENTO TRIBUTÁRIO NO BRASIL: FUNDAMENTAÇÃO LEGAL E PROCESSO CONSTITUCIONAL NO SUPREMO TRIBUNAL FEDERAL}

Marcus Livio

Professor Associado dos Programas de Bacharelado, Mestrado e Doutorado em Direito Tributário e Direito Tributário Internacional na Universidade do Estado do Rio de Janeiro, Brasil. Pesquisador Líder do Grupo de Projeto da BEPS (Base Erosion and Profit Shifting) da Universidade do Estado do Rio de Janeiro. Doutor e Mestre em Direito Tributário pela Universidade Complutense de Madrid, Espanha. Pósdoutorando no Instituto de Estudos Jurídicos Avançados (IALS / University of London). Juiz Federal do Tribunal Regional Federal da $2^{\mathrm{a}}$ Região. Rio de Janeiro/RJ. E-mail: marcusliviogomes@gmail.com

\section{Érico Pimentel}

Aluno do programa de Mestrado em Finanças Públicas, Tributação e Desenvolvimento da Universidade do Estado do Rio de Janeiro, Brasil. Procurador do Estado do Espírito Santo, Brasil.Vitória/ES. E-mail: ericopimente12007@yahoo.com.br

\begin{abstract}
As in many countries around the world, the debate about tax planning concerns its limits, and there is a clash between two perspectives on the subject. On the one hand, there is a traditional perspective, whose advocates argue for the need to preserve the legal security of the taxpayer and the use of a more formalist interception method of tax rules. On the other side is the contemporary perspective, which seeks to balance the need to
\end{abstract}

\footnotetext{
${ }^{1}$ Artigo recebido em 05/10/2018 e aprovado em 30/03/2019.
} 
Revista Eletrônica de Direito Processual - REDP.

Rio de Janeiro. Ano 13. Volume 20. Número 1. Janeiro a Abril de 2019

Periódico Quadrimestral da Pós-Graduação Stricto Sensu em Direito Processual da UERJ

Patrono: José Carlos Barbosa Moreira (in mem.). ISSN 1982-7636. pp. 362-383

www.redp.uerj.br

protect the taxpayer against abuse of tax authorities, but without neglecting the fact that the taxpayer sometimes practices abusive tax planning. At the center of this debate is the Federal Supreme Court (STF), a Brazilian constitutional court, which will examine the constitutionality of the sole paragraph of Article 116 of the National Tax Code, which for some academics is considered the Brazilian GAAR. The present paper aims to introduce and analyze some landmark points of the debate in Brazil, highlighting the legal reasoning deployed in this debate and the challenges for de constitutional process.

KEYWORDS: Brazilian Tax Planning; Legal Reasoning; Brazilian Supreme Court

RESUMO: Como em muitos países ao redor do mundo, o debate sobre planejamento tributário diz respeito a seus limites, e há um choque entre duas perspectivas sobre o assunto: por um lado, há uma perspectiva tradicional, cujos defensores argumentam pela necessidade de preservar a segurança jurídica do contribuinte e o uso de um método de interpretação mais formalista das regras fiscais; do outro lado está a perspectiva contemporânea, que procura equilibrar a necessidade de proteger o contribuinte contra o abuso das autoridades fiscais, mas sem negligenciar o fato de que o contribuinte às vezes pratica um planejamento tributário abusivo. No centro deste debate está o Supremo Tribunal Federal (STF), um tribunal constitucional brasileiro, que examinará a constitucionalidade do parágrafo único do artigo 116 do Código Tributário Nacional, que para alguns acadêmicos é considerado o GAAR brasileiro. O presente trabalho tem como objetivo apresentar e analisar alguns pontos marcantes do debate no Brasil, destacando o raciocínio jurídico empregado neste debate e os desafios para o processo constitucional.

PALAVRAS-CHAVE: Planejamento Tributário Brasileiro; Raciocínio Legal; Supremo Tribunal Federal

\section{INTRODUCTION}

Since the beginning of the 21 st century, due to a significant increase in tax avoidance, there has been a growing debate about tax planning. In its essence, the debate 
Revista Eletrônica de Direito Processual - REDP.

Rio de Janeiro. Ano 13. Volume 20. Número 1. Janeiro a Abril de 2019

Periódico Quadrimestral da Pós-Graduação Stricto Sensu em Direito Processual da UERJ

Patrono: José Carlos Barbosa Moreira (in mem.). ISSN 1982-7636. pp. 362-383

www.redp.uerj.br

seeks to find an adequate balance between individual freedom and public interest. The central issue of this controversy is relates to what should be the limit for disregarding a taxpayer's legal acts in order to 'reveal' taxable events supposedly hidden by those acts. Thus increasing importance has been conferred upon general anti-avoidance or anti-abuse rules (GAAR), which have been introduced in many jurisdictions to improve the capacity of the tax authorities to tackle, at least, the abusive forms of tax planning.

In general, anti-avoidance rules rely on the possibility of the administrative and judicial authorities' inquiry into the substance and purpose of the taxpayer's activities, setting aside the legal form adopted. It is recognized that without the power to proceed with this inquiry the GAARs may become fall ineffective, frustrating the social expectation to tackle activities considered abusive albeit legal. Nonetheless, the introduction of a GAAR must be performed within an adequate legal framework that ensures predictability and impartiality, as well having proper taxpayer safeguards against the tax authorities' abuses. This concern is particularly relevant in developing countries, where tax administration cannot always manage the level of discretion that a GAAR demands. In this process, the judiciary branch assumes a fundamental role once the judicial response will confirm or not of the legality of that inquiry.

In order to contribute to this debate, this paper intends to outline the Brazilian position concerning tax planning. It is not our intention to cover all the issues, since the complexity of the Brazilian tax system is an inexhaustible source of controversy. Our purpose is to show some landmark points of the debate in Brazil and demonstrate how it is developing, highlighting the academic debate and the legislative, administrative and judicial response concerning tax avoidance.

\section{A BRIEFLY RETROSPECTIVE OF BRAZILIAN ACADEMIC TAX PLANNING DEBATE}

In general, Brazilian academic authors highlight that the tax planning is the act of the taxpayer (business or individual) planning their economic activity to avoid or postpone 
Revista Eletrônica de Direito Processual - REDP.

Rio de Janeiro. Ano 13. Volume 20. Número 1. Janeiro a Abril de 2019

Periódico Quadrimestral da Pós-Graduação Stricto Sensu em Direito Processual da UERJ

Patrono: José Carlos Barbosa Moreira (in mem.). ISSN 1982-7636. pp. 362-383

www.redp.uerj.br

the occurrence of a taxable event or to reduce the tax liability. ${ }^{2}$ The controversy lies on the

limits between legitimate tax arrangements, aggressive tax planning or even tax evasion.

Like other parts of the world, there is no consensus of what effectively distinguishes one

from the other. The traditional criterion of legality ${ }^{3}$ is necessary but not sufficient to remove

all doubts, especially concerning aggressive tax planning. In the same way, the standard of chronology ${ }^{4}$, added by some authors, ${ }^{5}$ is not enough for adequate classification.

The debate about tax planning is embedded in a broader one, concerning how the various constitutional principles of taxation interact to define the very limits of tax liability. In contrast to common law jurisdiction, in Brazil there is no judicial decision issued by high courts (Supreme Federal Court and Superior Court of Justice) recognizing expressly the taxpayer's right to organize their business to reduce their taxation. However, in general, the authors recognize that tax planning is a constitutional right based on two sets of constitutional principles. The first is the general principle of economic freedom and autonomy of will, aspects of individual liberty that ensure a person's right to organize their economic life more efficiently. ${ }^{6}$ The second concerns the principle of the legality of the

\footnotetext{
${ }^{2}$ For instance, Heleno Taveira Tôrres note that tax planning is "the technique of preventive organization of business, aiming at the licit tribute economy" (Direito tributário e direito privado: autonomia privada, simulação e elusão tributária, v.1, $1^{\text {a }}$ ed., São Paulo: RT, 2003, p. 175); Marcus Abraham defines tax planning as 'the set of acts carried out by the taxpayer, individual or legal entity, which may be of an economic, accounting, legal or merely operational nature, in order to reduce in a licit and legitimate manner, totally or partially, the payment of taxes' (Curso de Direito Tributário Brasileiro, $1^{\text {a }}$ ed., Rio de Janeiro: Forense, 2018, p. 166).

${ }^{3}$ The traditional criteria that we refer are evidenced in recurrent definitions very similar to by those one given by Black's Law Dictionary. According to Black's Law Dictionary, tax avoidance is "the act of taking advantage of legally available tax-planning opportunities in order to minimize one's tax liability" and tax evasion is "the willful attempt to defeat or circumvent the tax law in order to illegally reduce one's tax liability".

${ }^{4}$ According to this standard, if the act that avoid, reduce or deferred the taxable fact is prior to the occurrence of the taxable activity, it is tax avoidance and legal; however, if the act is after the taxable activity, will be tax avoidance and, therefore, illegal.

${ }^{5}$ For instance, Hermes Marcelo Huck (Evasão e elisão: rotas nacionais e internacionais. São Paulo: Saraiva, 1997, p. 28).

${ }^{6}$ Alberto Xavier notes that "the individual freedom of private individuals to organize and contract in a less taxing way is one of the most noble themes of Tax Law, closely linked, as it is to the individual guarantees that aim to protect it and which consist of the principles of legality and certainty of taxation" (Tipicidade da Tributação, Simulação e Norma Geral Antielisiva. São Paulo: Dialética, 2001, p 3). In the same way, Ricardo Lobo Torres points out 'the taxpayer is free to conduct his or her business in the way that best suits him' and 'freedom of initiative is a starting point for economic life and cannot be interfered by the State (Planejamento Tributário: elisão abusiva e evasão fiscal. São Paulo: Elsevier, 2013, p. 10); Marco Aurélio Grego observe that '[the] theme of tax planning is linked to the exercise of individual freedom to organize life in the search for the lowest tax burden allowed by the legal system. This organization takes place through the celebration of acts or legal transaction of the most diverse nature, which, for the most part, are provided for in the Civil Code, either as typical contracts, or as to the elements and requirements of the legal transactions in general' (Planejamento tributário, $3^{\mathrm{a}}$ ed., São Paulo: Dialética, 2008, p. 503).
} 
Revista Eletrônica de Direito Processual - REDP.

Rio de Janeiro. Ano 13. Volume 20. Número 1. Janeiro a Abril de 2019

Periódico Quadrimestral da Pós-Graduação Stricto Sensu em Direito Processual da UERJ

Patrono: José Carlos Barbosa Moreira (in mem.). ISSN 1982-7636. pp. 362-383

www.redp.uerj.br

taxation, which protect the taxpayers against imposition without statute and makes legal certainty and non-retroactivity of taxation recognized as taxpayers' fundamental rights.

On another hand, more recently, some authors highlight the social interest concerning the integrity of taxation. The integrity is sought by raising taxes from those who can pay and by tackling abusive tax planning and tax evasion, ensuring the realization of the fundamental duty of paying taxes, with equal constitutional dignity. ${ }^{7}$

Specifically, the debate focuses on how those principles interact with each other in order to protect individual liberty and, at the same time, to providing revenue for financing public expenditure. It is impossible to draw a complete and hard distinction between the distinct views adopted by Brazilian academics concerning tax planning. However, might be useful to distinguish two main views: traditional and contemporary views. ${ }^{8}$

The traditional view ${ }^{9}$ was predominant in Brazil during the second half twentieth century and has its philosophical foundations in the formal positivism and in the jurisprudence of concepts. It has a deep distrust of public tax authorities, whose powers must be limited and should be granted only what is strictly necessary for the exercise of its attributions, removing any margin of discretion in the application of the tax law to the facts. ${ }^{10}$ According to this perspective, the principle of legality prescribes not only prior authorization

\footnotetext{
${ }^{7}$ Marcus Abraham points out that the "fundamental duty to pay taxes is constituted by the realization of the principles of contributory capacity [ability to pay], human dignity and solidarity, as constitutional expressions of a public fiscal ethic" (Curso de Direito Tributário Brasileiro, $1^{\mathrm{a}}$ ed., Rio de Janeiro: Forense, 2018, p. 53). According to Brazilian Constitution, the principle of human dignity is fundamental principles that Brazilian society is grounded (art. 1, III). The solidarity is a constitutional objective Brazilian society (art. 3, I, 'The fundamental objectives of the Federative Republic of Brazil are... to build a free, just and solidary society'). The ability to pay principle also has specific tax constitutional provision (art. 145, $\S 1^{\circ}$, 'Whenever possible, taxes shall have an individual character and shall be graded according to the economic capacity of the taxpayer'). All these constitutional principles have inspired Brazilian tax policies creating duties that, besides not expressly written in a constitutional rules binding on all members of society, among them, the fundamental duty of pay tax. As Marcus Abraham concludes, according to Brazilian constitutional law, 'there is no way to refute the conclusion that in order to pragmatically support the social pact and the fundamental right to the freedom and dignity of the human person, there will also be a burden [...] such price would is the fundamental legal duty to pay taxes'.

${ }^{8}$ We use this classification has the only descriptive purpose, to further the understanding of the Brazilian debate, and considers the criterion of moment of appearance of currents of thought (traditional, first in time; contemporary, after that). There is no evaluation about whether one is better or worse than the other one.

${ }^{9}$ The main authors that defends this perspective are Alberto Xavier (author of the seminal book Tipicidade da Tributação, Simulação e Norma Geral Antielisiva. São Paulo: Dialética, 2001), Roque Antonio Carrazza (Curso de Direito Constitucional Tributário, $2^{\mathrm{a}}$ ed., São Paulo: Malheiros, 2017); Ives Gandra Martins (Teoria da Imposição Tributária. São Paulo: LTr, 1988); Sacha Calmon Navarro Coêlho (Curso de Direito Tributário Brasileiro, $15^{\mathrm{a}}$ ed., São Paulo: Forense, 201); and Hugo de Brito Machado (Os Princípios Jurídicos da Tributação na Constituição de 1988, $5^{\text {a }}$ ed., São Paulo: Dialética, 2004)

${ }^{10}$ ROCHA, Sérgio André Rocha. Da Lei à Decisão, $1^{\text {a }}$ ed., Rio de Janeiro: Lumen Juris, 2017, p. 23
} 
Revista Eletrônica de Direito Processual - REDP.

Rio de Janeiro. Ano 13. Volume 20. Número 1. Janeiro a Abril de 2019

Periódico Quadrimestral da Pós-Graduação Stricto Sensu em Direito Processual da UERJ

Patrono: José Carlos Barbosa Moreira (in mem.). ISSN 1982-7636. pp. 362-383

www.redp.uerj.br

in the statute to raises taxes but also that this statute must bring an accurate and rigid description of the event which affects the tax liability of a person. In other words, the description of a taxable event in the legal norm must be detailed and expressed in a clear and specific way, and not just broad descriptions of economic activities.

The traditional methodology is based on the concept of tipos tributários fechados (strict taxable event construction) from which is found the princípio do tipo fechado (literally, principle of closed tax type, quite similar to the common law principle of strict construction of taxing statutes). Traditional academics introduced an analogy between the description of the taxable event in the statute and the description of the criminal offence in the penal law. Thus, in the same fashion as the penal law, in which a person cannot be prosecuted on the basis of extensive interpretation of the penal statutes, the taxation statutes cannot be extensibly interpreted to recognize tax liability. In this case, taxpayers are not subject to tax unless they fall in the literal words of the statute. ${ }^{11}$

Moreover, for legitimate levying taxes, not only must the taxable event description ('type') be detailed, clear and certain ('closed') but so must the facts that supposedly create the tax liability be. The tax law statutory interpretation would be an activity that requires a formal syllogism where clear legal provisions are applied equally clear facts. As a consequence, an event is not taxable if it does not fit as literally described in the statutes, though it could constitute evidence of wealth compatible with the spirit of the legal rule. Accordingly, in this last case, the solution cannot be found in fitting such a case into the existing taxable event description. Parliament must enact another law, allowing a levy tax in this case, bridging the loophole or updating the obsolete legislation. The taxpayer cannot be responsible because of the delay of a legislator or by the fact that the law is incompatible with the new economic realities. Due to the prevalence of the traditional view

\footnotetext{
${ }^{11}$ Some Brazilian authors defend that the level of legal protection in the tax field is superior to criminal. See, e.g. Sacha Calmon Navarro Coêlho: "compared with the Criminal Law, it is verified that the taxation norm is more rigid. In criminal law, nullum crime, nulla poena sine lege requires that the offense be typical, [that is] derives from a precise legal prediction, but it allows the judge, when sentencing, the dosimetry of the sentence, with relative freedom, as well as diminish and loosen the penalty a posteriori. In Tax Law, in addition to demanding the taxable event, the duty to pay the tax must also be paid in all its elements, since here the taxes and their payment are important, based on the quantification formulas of the due benefit, and which society demands must be rigid and intractable" (Curso de Direito Tributário Brasileiro, 15ª ed., São Paulo: Forense, 2017, p. 140).
} 
Revista Eletrônica de Direito Processual - REDP.

Rio de Janeiro. Ano 13. Volume 20. Número 1. Janeiro a Abril de 2019

Periódico Quadrimestral da Pós-Graduação Stricto Sensu em Direito Processual da UERJ

Patrono: José Carlos Barbosa Moreira (in mem.). ISSN 1982-7636. pp. 362-383

www.redp.uerj.br

in the last decades of the twentieth century, the Brazilian response to abusive tax planning was performed through punctual corrections of legislation.

In the 1970s the contemporary view emerged, which comprises many theories of tax legal reasoning critical to legal formalism. Inspired by the jurisprudence of values, ${ }^{12}$ all these theories have in common a reappraisal of the traditional assumption that tax law interpretation is a matter of formal syllogism and that the legal tax terms can have only one meaning. ${ }^{13}$ Besides, this perspective claims that the facts concerning tax liability must be considered not only in their legal form but also regarding their purpose and economic result. Proponents of the contemporary view argue that the traditional framework went too far in its theoretical model, conferring the same or even more prominent level of constitutional protection reserved for the freedom to property rights. ${ }^{14}$ They argue that the interpretation of the tax law and its underlying facts has a degree of uncertainty, especially when considering complex economic realities such as immaterial richness (e.g. intellectual property in biotechnology) and new forms of creation and circulation of values (e.g. ecommerce and digital economy). According to this view, the new and complex scenario claims new ways to interpret tax provisions and facts. In this new scenario, a broader approach to address the issue of tax avoidance was adopted, raising questions about the limits of the administrative tax authorities in the interpretation of the tax statutes and facts. ${ }^{15}$

The contemporary view does not deny that the tax law needs to ensure legal certainty. However, it claims that the legal terms deployed in tax rules (e.g. business, income and so on) are necessarily elastic and polysemic, representing 'the average or the normality

\footnotetext{
${ }^{12}$ See, e.g., Marcus Abraham (A Segurança Jurídica e os Princípios da Legalidade e da Tipicidade Aberta in: RIBEIRO, Ricardo Lodi; RIBEIRO, Ricardo Lodi; ROCHA, Sergio André (Orgs.). Legalidade e tipicidade no Direito Tributário. São Paulo: Quartier Latin, 2008, p. 57-58)

${ }^{13}$ Ricardo Lobo Torres, late professor of tax law at the Rio de Janeiro State University made influential defense of this perspective. Among the works of Ricardo Lobo Torres must be cited: Normas de Interpretação $e$ Integração do Direito Tributário, $4^{\mathrm{a}}$ ed., Rio de Janeiro: Renovar, 2006; Tratado de Direito Constitucional Financeiro e Tributário, $3^{\mathrm{a}}$ ed., Rio de Janeiro: Renovar, 2014; Planejamento Tributário: elisão abusiva e evasão fiscal. São Paulo: Elsevier, 2013.

${ }^{14}$ See, e.g., the critical analyses of Sérgio André Rocha: "This insistence on the comparison between Tax Law and Criminal Law always surprised me. Firstly, assimilation between the legal freedom and the legal good patrimony, as if the protection of property and freedom was in the same level. Second and foremost, it surprises me the comparison since the Criminal Law has always lived with the indeterminate concepts that populate the Penal Code, and so-called blank criminal standards, which depend on of administrative integration, both concepts that repudiate defenders of strict legality and closed-type nature.'(Da Lei à Decisão, $1^{\mathrm{a}}$ ed., Rio de Janeiro: Lumen Juris, 2017, p. 6).

${ }^{15}$ GOMES, Marcus Lívio. A Interpretação da Legislação Tributária, $1^{\text {a }}$ ed., Rio de Janeiro: Quartier Latin, 2010, p. 67-68.
} 
Revista Eletrônica de Direito Processual - REDP.

Rio de Janeiro. Ano 13. Volume 20. Número 1. Janeiro a Abril de 2019

Periódico Quadrimestral da Pós-Graduação Stricto Sensu em Direito Processual da UERJ

Patrono: José Carlos Barbosa Moreira (in mem.). ISSN 1982-7636. pp. 362-383

www.redp.uerj.br

of a given concrete situation, obtained by induction from social reality'. ${ }^{16}$ According to this view, the level of certainty claimed by the traditional perspective is impossible to reach.

The overview allows us to observe two significant facts. The traditional perspective creates a legal environment favourable to tax planning, especially the aggressive one. At the same time that this view confers full freedom to the person to handle legal forms to avoid taxation, it constrains administrative and judicial authorities power to tackle abusive tax planning. Only through a particular provision in the statute can the particular loopholes or unattended consequences of the legislation be solved. On the other hand, the contemporary perspective gives more room to administrative and judicial authorities and increases its participation in the legal reasoning in defining taxation issues, including the bridging of loopholes and the rapid correction of unattended consequences. As for the legislative branch, it creates a constitutional environment to legitimise the adoption of general rules concerning tax avoidance.

\section{BRAZILIAN LEGISLATIVE AND ADMINISTRATIVE RESPONSE}

Changing our focus to the government responses, nominally the legislative and executive branches, our purpose is to give a brief overview of how the Brazilian authorities have reacted to the changes in the views about tax planning.

\subsection{The legislative response}

In 2001, Brazilian Congress enacted the Supplementary Law $\mathrm{n}^{\circ} 104$, which amended the Brazilian National Tax Code to include an anti-circumvention clause inspired by the French model ${ }^{17}$. The reasons for the statute subscribed by the Minister of Finance make clear that the aim of the new provision is to clarify, under Brazilian law, a rule that allows the authority to disregard acts or legal transactions carried out only for tax purposes

\footnotetext{
${ }^{16}$ ABRAHAM, Marcus, op. cit., p. 106.

${ }^{17}$ Código Tributário Nacional, Article 116, sole paragraph.
} 
Revista Eletrônica de Direito Processual - REDP.

Rio de Janeiro. Ano 13. Volume 20. Número 1. Janeiro a Abril de 2019

Periódico Quadrimestral da Pós-Graduação Stricto Sensu em Direito Processual da UERJ

Patrono: José Carlos Barbosa Moreira (in mem.). ISSN 1982-7636. pp. 362-383

www.redp.uerj.br

and thus provide a useful instrument for combating tax planning practiced with abuse of form or law. ${ }^{18}$

It is essential to highlight that the Brazilian National Tax Code was enacted in 1966 when the traditional perspective was hegemonic. In its original words, it brought only one specific rule about tax avoidance and evasion, which allow administrative authorities to review taxpayers' tax statements in the case of fraud or deception. ${ }^{19}$ Considering the power constraints of administrative authorities, the application that rules had a central focus on cases of more straitened circumstances, where the taxpayer's conduct could be considered sufficiently unlawful to be almost considered a tax offence. In this context of the limitation of administrative and judicial powers, the primary technique to deal with undesirable tax planning was through the legislative process, which enacted a large number of statutes to address specific tax planning schemes and conceptual issues. ${ }^{20}$

Through the Supplementary Law n. 104, the Congress added a general provision to the Brazilian National Tax Code, prescribing that the administrative authority's powers to disregard legal acts or transactions carried out concealing (dissimulating) the taxable event or the nature of the elements of the tax obligation. The rule raises questions about its nature.

Interpreting the provision, some commentators argue that new art. 116, sole paragraph, of Brazilian National Tax Code, does not introduce the GAAR but intends only

\footnotetext{
${ }^{18}$ ABRAHAM, Marcus. Os 10 anos da Norma Geral Antielisiva e as Cláusulas do Propósito Negocial e da Substância sobre a Forma Presentes no Direito Brasileiro. Revista Dialética de Direito Tributário, Rio de Janero, n. 80, 2011, p. 192.

${ }^{19}$ Código Tributário Nacional Article. 148 III.

${ }^{20}$ Marcus Abraham reports some examples of specific anti-circumvention: "Decree-Law n. 1.598/1977, which restricted the disguised distribution of profits; Law n. 7.450/1985, which included within its scope of income all earnings and income regardless of denomination adopted; Law n. 7.713/1988, when establishing that the taxation is independent of the denomination given to the earned gains and income earned; Law n. 9.249/1995, which adopted the principle of the universality of taxation on the income of legal entities that have links with other companies of the same group abroad, in order to reduce the use of tax havens; the prohibition against the use of tax losses of companies, introduced by Decree-Law n. 2.341/1987 [...] establishing that the successor legal entity by incorporation, merger or spin-off cannot offset tax losses of the successor; Supplementary Law n. 104/2001, which includes in the concept of Income Tax a mechanism that makes it difficult to elucidate manipulations by means of revenue denominations or income, location, legal status, nationality of the source or form of perception, as well as when the income from abroad is available; Provisional Measure n. 2.158$35 / 2001$, which amended the tax treatment of profits, income and capital gains earned abroad by legal entities domiciled in the country; Law n. 9.311/1996, which restricted the negotiation and circulation of checks through endorsements, inhibiting the tax avoidance of the Provisional Contribution on Financial Transactions; Laws n. 8.981/1995 and 9.311/1996, establishing that the incidence of Income Tax and Provisional Contribution on Financial Transactions is not dependent of its name or the instrument used."(op. cit., p.183).
} 
Revista Eletrônica de Direito Processual - REDP.

Rio de Janeiro. Ano 13. Volume 20. Número 1. Janeiro a Abril de 2019

Periódico Quadrimestral da Pós-Graduação Stricto Sensu em Direito Processual da UERJ

Patrono: José Carlos Barbosa Moreira (in mem.). ISSN 1982-7636. pp. 362-383

www.redp.uerj.br

to make evident the administrative authorities' power to act against some cases of simulations that, although they should not be declared null and void, cannot generate effects for tax purposes. ${ }^{21}$ In this sense, the provision regulates aspects of the traditional hypotheses of simulation and defines the competence of the administrative authority. These commentators argue that the interpretation of this provision as a general anti-avoidance rule would violate the principle of legality and strict taxable event construction. However, the majority of the Brazilian authors believe that art. 116, sole paragraph, of Brazilian National Tax Code introduced a general anti-avoidance rule. For these authors, the rule allows legal arrangements to be disregarded when there is an abuse of legal forms or no business purpose, authorizing the levying of tax when the principal purpose of the specific transaction is the reduction of tax. In this context, the efficacy of tax planning against the tax authorities is subject to two conditions: first, it requires a primary negotiation purpose for the operation, in addition to the tax savings purpose; secondly, the operations must have a legal and factual existence, it not being enough that the legal form adopted is lawful. In this sense, the new provision broadens the power of inquiry into the tax arrangements, allowing the tax authority to introduce a new legal qualification called dissimulation.

According to some academic authors, the rule of article 116, sole paragraph, would not be applicable until another specific law has introduced to discipline the procedure to be adopted by the tax authority. In 2002, an attempt was made to regulate this procedure, through Provisional Measure n. 66/2002. The Article 14 of Provisional Measure n. 66/2002, provided that acts or legal transactions that are aimed at reducing the value of tax, avoiding or delaying its payment, or concealing the real aspects of the taxable event or the real nature of the constituent elements of the tax obligation, are subject to disregard. It was the first time in Brazil that a legal rule expressly adopted the business purpose and the substance over the form tests. ${ }^{22}$ The rule was considered indicative of a lack of business purpose to taxpayers' choice for the most complex or costly, between two or more forms for the practice of a particular act. ${ }^{23}$ The rule also conceptualized abuse of legal form as the practice of an indirect legal act or business that produces the same economic result of the act or legal business

\footnotetext{
${ }^{21}$ COÊLHO, Sacha Navarro Coêlho. op. cit., p. 158-159.

${ }^{22}$ Medida Provisória n. 66 de 22 de julho de 2015 Article 14 Paragraph 1.

${ }^{23}$ Medida Provisória n. 66 de 22 de julho de 2015 Article 14 Paragraph 2.
} 
Revista Eletrônica de Direito Processual - REDP.

Rio de Janeiro. Ano 13. Volume 20. Número 1. Janeiro a Abril de 2019

Periódico Quadrimestral da Pós-Graduação Stricto Sensu em Direito Processual da UERJ

Patrono: José Carlos Barbosa Moreira (in mem.). ISSN 1982-7636. pp. 362-383

www.redp.uerj.br

concealed. ${ }^{24}$ However, the Congress did not approve those provisions, leaving them without binding legal effect.

On 22 July 2015, the Executive Branch enacted the Provisional Measure n. 685. The rule provided an obligation to declare operations involving aggressive tax planning. The Article 7 provided mandatory disclosure of taxpayer's acts that result in suppression, reduction or deferral of tax when: (a) the acts or legal transactions practiced have no other business purpose than tax economy; (b) the form adopted is not usual, uses indirect transactions or contains specific clauses that modify, even partially, the effects of a typical contract; or (c) to deal with specific acts or legal transactions provided for in an act of the Brazilian Federal Revenue Service. Additionally, the Article 11 prescribed that the taxpayer's statement under Article 7 should be considered ineffective when: (a) submitted by anyone who is not the taxpayer of any tax obligations resulting from the transactions related to the declared legal acts or businesses; (b) verified omission in relation to data essential for the understanding of the legal act or transactions; (c) contains material or ideological falsity; and (d) involves fraudulent interposition of persons. Also, the rule provided that the failure of the taxpayer to mandatory disclosure or if the taxpayer's statement is considered ineffective under Article 11, would be characterized as tax evasion, having as a consequence a fine of $150 \%$ on the amount of the tax due and criminal investigation.

The Brazilian tax authorities declared that the rule aimed to introduce a closer relationship between the taxpayer and the Brazilian Federal Revenue increases legal certainty and reduces litigation. Still, according to them, the rule sought to align the Brazilian legal framework with the method of tax planning oversight preconized by the OCDE in the Action 12 of program BEPS (Base Erosion and Profit Shifting). Indeed, it is well known that the one approach adopted by legislators around the world is to address the increasing activity of tax avoidance is the introduction of mandatory disclosure rules. ${ }^{25}$ However, the method and concepts adopted by Provisional Measure n. 685 raised concerns about the rule.

In public hearings before a Brazilian Congress' commission, many tax specialists call attention to the fact that the rule in practice presumes fraud and tax evasion

\footnotetext{
${ }^{24}$ Medida Provisória n. 66 de 22 de julho de 2015 Article 14 Paragraph 3.

${ }^{25}$ DUFF, David G. Tax Avoidance in the 21st Century. Australian Business Tax Reform Retrospect and Prospect, 2019. Disponível em <https://ssrn.com/abstract=1457453>. Acesso em: 12 jul. 2018, p. 479.
} 
Revista Eletrônica de Direito Processual - REDP.

Rio de Janeiro. Ano 13. Volume 20. Número 1. Janeiro a Abril de 2019

Periódico Quadrimestral da Pós-Graduação Stricto Sensu em Direito Processual da UERJ

Patrono: José Carlos Barbosa Moreira (in mem.). ISSN 1982-7636. pp. 362-383

www.redp.uerj.br

in aggressive tax planning. This situation exposes the taxpayers and advisors to severe consequences if the Federal Revenue, at its discretion, decides that the taxpayer has not complied the duty prescribed in Article 7 or considers the disclosure ineffective under Article 11. Indeed, the question of penalties for dealing with non-compliance deserves close attention because its exaggeration may lead to serious questions about its constitutionality and even its morality. It is worth noting that on 11/3/2015 - only a few months before the Provisional Measure $\mathrm{n}^{\circ} 685$, therefore - the OCDE had submitted for public discussion its first draft about mandatory disclosure. The draft contained some examples of monetary penalties (e.g. daily penalties, penalty proportionate to tax savings or promoter fees) and non-monetary penalties (e.g. suspension of the efficacy of the tax planning scheme) to deal with non-compliance. None of them indicate a presumption of fraud and criminal offence or imposing extraordinarily high monetary penalties. ${ }^{26}$ In response to backlash, the Brazilian Congress rejected the mandatory disclosure.

\subsection{Administrative tax authorities response}

The hesitant legislative activity did not prevent the administration from advancing in its attempt to control tax avoidance activity. The Conselho Administrativo de Recursos Fiscal (CARF), the main administrative tax council in Brazil, has developed an essential role in the analysis of tax planning transactions in the absence of more specific legislation.

There is no need here to deal with the CARF's jurisprudence on tax planning with details. It is sufficient to highlight two aspects of the tax council that reflect the Treasury policy on tax planning. Firstly, though the administrative council had adopted a more formalistic view until mid-2010, subsequent decisions have shown the council's trend of adopting business purpose and substance over form test to identify abusive tax planning. Secondly, this change has been considered as a result of the application of U.S. tax law

\footnotetext{
26 OCDE, Mandatory Disclosure Rule, Action 12 - 2015 - Final Report, 2015, Disponível em <https://read.oecd-ilibrary.org/taxation/mandatory-disclosure-rules-action-12-2015-finalreport_9789264241442-en\#page2>. Acesso em 8 jul. 2018.
} 
Revista Eletrônica de Direito Processual - REDP.

Rio de Janeiro. Ano 13. Volume 20. Número 1. Janeiro a Abril de 2019

Periódico Quadrimestral da Pós-Graduação Stricto Sensu em Direito Processual da UERJ

Patrono: José Carlos Barbosa Moreira (in mem.). ISSN 1982-7636. pp. 362-383

www.redp.uerj.br

doctrines, giving to council new legal reasoning to adopt new interpretation to old statue provision about simulation, rather than as response the reason of a new legal provision.

The council does not explicitly recognize this influence. However, it is evident in the council's legal reasoning, whose premises are very similar to those adopted by Judge Learned Hand and endorsed by U.S. Supreme Court in Gregory v. Helvering, ${ }^{27}$ and the council's method of adjudication that give great emphasis on circumstantial evidence (element subjective of transaction) and the economic result of the transaction (element objective).

\section{BRAZILIAN SUPREME COURT RESPONSE}

What about the judiciary branch? Unlike what happened in the United States, United Kingdom and Canada, the Brazilian Supreme Federal Court (Supremo Tribunal, hereinafter referred as STF) has no decision expressly endorsing any perspective about tax planning or outlining the role and powers of administrative and judicial authorities in this question. The constitutional challenge of article 116, sole paragraph, of the Brazilian National Tax Code, in the ADI no 2.446 is the opportunity to the STF gives its view about tax planning.

Furthermore, is it possible to ascertain any indication of how the STF will (try to) resolve this debate? Of course, it is not our aim to predict the decision of the Constitutional court, which is impossible in particular given the Supreme Court's history of change of understanding due to the renovation of its composition. We must highlight some aspects of the legal reasoning in recent STF's decisions that can give us the trend of the Court. However, before presenting that point, it might be relevant show a brief analysis of the arguments articulated in $A D I 2.446 .{ }^{28}$

\subsection{ADI 2.446. What is the case?}

${ }^{27}$ SUPREME COURT OF UNITED STATES. Gregory v. Helvering, 293 U.S. 465 (1935). Argued December 4, 5, 1934. Decided January 7, 1935. Disponível em < https://supreme.justia.com/cases/federal/us/293/465/>, Acesso em 5 out 2018.

${ }^{28}$ Supremo Tribunal Federal. Ação Direta de Inconstitucionalidade (ADI) n. 2446. 
Revista Eletrônica de Direito Processual - REDP.

Rio de Janeiro. Ano 13. Volume 20. Número 1. Janeiro a Abril de 2019

Periódico Quadrimestral da Pós-Graduação Stricto Sensu em Direito Processual da UERJ

Patrono: José Carlos Barbosa Moreira (in mem.). ISSN 1982-7636. pp. 362-383

www.redp.uerj.br

In 2001, the claimant, a trade representative association, issued a constitutional challenge against the article 116, sole paragraph, of the Brazilian National Tax Code. According to the claimant, the challenged rule gives to the administrative tax authority the power to assess the tax event, with a focus not on legally issued documents evidencing the operation, but on the operations that it is supposed may be covered up (disguised or feigned) by a legal entity to reduce the tax liability. Therefore, the provision allows the tax authority to disregard the legal form adopted by the taxpayer, even though it was done in compliance with the rules. As a result, the claimant argues, the rule forbids the tax planning. It also argues that the taxpayers have the right to manage their business as economically as possible, including to save taxes throughout tax planning, realized in the 'field of lawful, legal, permitted, taking advantage of 'loopholes' of the law.'

In this sense, the claimant observes that the tax planning occurs in 'spaces left by loopholes in tax law, not filled by the inadvertence of the legislator' and through the use of step transactions, that "consists in the use of operations or legal transactions that configure situations that lead to pay less tax'. Finally, it argues that the challenged rule allows the tax authority to fill the loopholes in the legislation, acting as legislator, importing violation of the principle of the strict description of taxable events and the principle of separation of powers, as well as allowing the taxation by analogy.

In its response, the government argues that the rule does not become forbid legal tax planning, but only illegal or abusive instances. The government says that the rule aims to make clear the possibility of assessing step transactions and the use of business purpose test, tackling the abuse of legal form, deployed to avoid or reduce tax liability. In this sense, the government refuses the rule interpretation as a means of tackling simulation, which practice was already forbidden in another provision of the Brazilian National Tax Code. Additionally, it was noted that there is no taxation by analogy applying the rule, because, through the rule, the tax authority reveals the taxable event as described in the tax statute. There is no creation of a new taxable event by the tax authority.

From both arguments, two questions can be raised. Firstly, is there a principle of strict taxable event description in the constitution? Secondly, does the STF establish the features that distinguish legitimate tax planning from an abusive or unlawful one? Let us move on to the possible answers to those questions. 
Revista Eletrônica de Direito Processual - REDP.

Rio de Janeiro. Ano 13. Volume 20. Número 1. Janeiro a Abril de 2019

Periódico Quadrimestral da Pós-Graduação Stricto Sensu em Direito Processual da UERJ

Patrono: José Carlos Barbosa Moreira (in mem.). ISSN 1982-7636. pp. 362-383

www.redp.uerj.br

4.2. Is there a constitutional principle of strict taxable event description?

The response of this first question can be reached analyzing the legal reasoning in two decisions of the STF: RE 343.446, ${ }^{29}$ of 4.4.2004, and ADI 4.697, of 06.10.2016.

In the $R E$ 343.446, Brazilian Supreme Court analysed the case of a tax contribution called 'labor accident insurance'. The challenged tax provision prescribes that companies shall contribute to financing the public health system through tax calculated according to the risks of labor accident to which their workers are exposed. The statute prescribes risk categories: the higher the risk, the higher the tax rate. However, these categories were defined widely through the expressions 'preponderant activity' and 'light, medium and severe degree'. The provisions delegate power to the executive branch to define which business activities fall into each of these categories. The question raised before the STF was whether the expressions 'preponderant activity' and 'light, medium and severe degree' could be used in the tax statute, considering the existence of a supposed principle of strict taxable event description (also referred as strict legality). The Court found constitutional those expressions, and ruled that those broader expressions are enough to attend the principle of legality and define the tax liability.

It is important to note that in $R E 343.446$ the STF does not expressly reject the principle of strict taxable event description, which happened only in 2016. In the ADI $4.697,{ }^{30}$ of 06.10 .2016 , the STF faced the question expressly, ruling that the principle of legality in taxation does not implicate the adoption of the doctrine of strict taxable event construction. Justice Edson Fachin, writing for the majority, stated that the so-called principle of strict taxable event construction as defined by the traditional Brazilian view, would conduct to the unfeasibility of taxation in the country or, at least, assume it overcame the model of formal legalism.

Of course, it does not mean that the Court would admit taxation by analogy. It means that the description of the taxable event can use broader terms in order to levy tax from those that use the legal forms to avoid taxation. Therefore, the Supreme Court would reject the argument that the Brazilian Constitution protect the taxpayer in the same way that

\footnotetext{
${ }^{29}$ Supremo Tribunal Federal, Recurso Extraordinário (RE) no 343.446.

${ }^{30}$ Supremo Tribunal Federal, Ação Direta de Inconstitucionalidade (ADI) no 4.697.
} 
Revista Eletrônica de Direito Processual - REDP.

Rio de Janeiro. Ano 13. Volume 20. Número 1. Janeiro a Abril de 2019

Periódico Quadrimestral da Pós-Graduação Stricto Sensu em Direito Processual da UERJ

Patrono: José Carlos Barbosa Moreira (in mem.). ISSN 1982-7636. pp. 362-383

www.redp.uerj.br

citizen against criminal charges, as well as would not endorse, the traditional English interpretative doctrine that tax statutes must be construed strictly.

4.3. Will the Brazilian Supreme Court establish the features that distinguish the legitimate tax planning from an abusive or unlawful one?

The second question demands the analyses of two elements in the Supreme Court's tax legal reasoning in constitutional process. Firstly, the recognition of the duty of paying taxes as a fundamental one ${ }^{31}$, with the increasing perception that the government must have the power to tackle the taxpayer's misconduct in taxation matters. Secondly, the STF's growing attention to the arguments of policies in the court's legal reasoning. Some cases will illustrate those trends.

In $A D I 2.390$ the Court ruled on the constitutionality of the tax provision that allows administrative tax authorities the access taxpayer's bank information to identify tax evasion schemes. The constitutional challenge was grounded in the argument that only judicial authorities can order breaking banking secrecy according to the Brazilian Constitution. The STF found the rule constitutional, noting that the payment of taxes is a fundamental duty, and tax must be seen as an indispensable contribution of the person to society. In other words, taxation shall not be considered 'a mere exercise of power by the state, or as a sacrifice for the citizen'. In this context, STF highlights the solidarity nature of the tax, 'which is owing by the citizen by the simple fact of belonging to the society.' Therefore, the fundamental duty to pay taxes is based on the idea of social solidarity whose constitutional foundation is Article 3, III, of the Brazilian Constitution. From that conclusion, the Supreme Court also recognized that 'since it represents the contribution of each citizen to the maintenance and development of a State that promotes fundamental rights, it is necessary to adopt effective mechanisms to combat tax evasion.'

\footnotetext{
${ }^{31}$ The idea of a fundamental duty (as oppose of fundamental rights) was introduced in Brazil throughout the idea developed by Portuguese professor José Casalta Nabais in the work O Dever Fundamental de Pagar Impostos (Coimbra: Livraria Almedina. 2004.). According to this author, could be extracted from the Portuguese constitutional framework the implicit fundamental duty to pay taxes. The doctrine was introduced with remarkable success in Brazil, which was already quite permeable to the influences of the doctrine of Portuguese Constitutional Law, especially after the J.J Gomes Canotilho e Vital Moreira's book Direito Constitucional e Teoria da Constituição (Coimbra: Livraria Almedina. 2004)
} 
Revista Eletrônica de Direito Processual - REDP.

Rio de Janeiro. Ano 13. Volume 20. Número 1. Janeiro a Abril de 2019

Periódico Quadrimestral da Pós-Graduação Stricto Sensu em Direito Processual da UERJ

Patrono: José Carlos Barbosa Moreira (in mem.). ISSN 1982-7636. pp. 362-383

www.redp.uerj.br

The Court's legal reasoning is directed to tackle tax evasion cases and not tax

avoidance schemes. However, it endorses the assumption of taxation as a duty due to social solidarity and any attempt to avoid this duty must be grounded in relevant arguments of a similar nature. However, until the present moment, as seen above, the traditionalist perspective offered no argument that could reconcile a strict interpretation of the tax provisions with the solidarity inherent in the social state.

Furthermore, it must be noted that in $A D I 2.390^{32}$, the Supreme Court gave particular relevance to the policy arguments in its decision. The Constitutional Court emphasizes the fact of the Brazilian government assumed the commitment before the Global Forum on Transparency and Exchange of Information for Tax Purposes, 'to comply with international standards of transparency and exchange of banking information, established in order to avoid noncompliance with tax rules, as well as to combat criminal practices.' The STF also notes that, without the mechanisms to access taxpayers' banking information by the tax administration, the Brazil government would not comply with its international commitments. Then, it is clear that the STF also considered policy argument to refuse the constitutional challenge.

In ADI 2.390 the use of policy arguments could be seen as unnecessary because there were clear constitutional parameters to solve the question. However, STF has used policies arguments to rule about the constitutional controversy when the constitutional parameter is not explicit.

In $A D I 2.588^{33}$ and RE $611.586^{34}$, the Brazilian Supreme Court considered central to the solution of the constitutional dispute the political relevant purpose of the challenged rule. The rule allowed taxation on all undistributed profits of controlled foreign companies or affiliated companies of Brazilian resident entities. The complaint's main argument was that undistributed profits could not be considered income as established by the Brazilian Constitution for tax purpose. Therefore, the taxation on those profits would be unconstitutional. In this case, the STF found the constitutional rule concerning foreign affiliated companies located in a jurisdiction qualified as low-tax jurisdiction and/or listed as a privileged tax regime according to the specific law. However, the rule was found

\footnotetext{
${ }^{32}$ Supremo Tribunal Federal, Ação Direta de Inconstitucionalidade (ADI) n. 2.390.

${ }^{33}$ Supremo Tribunal Federal, Ação Direta de Inconstitucionalidade (ADI) n. 2.588.

${ }^{34}$ Supremo Tribunal Federal, Recurso Extraordinário (RE) n. 611.586.
} 
Revista Eletrônica de Direito Processual - REDP.

Rio de Janeiro. Ano 13. Volume 20. Número 1. Janeiro a Abril de 2019

Periódico Quadrimestral da Pós-Graduação Stricto Sensu em Direito Processual da UERJ

Patrono: José Carlos Barbosa Moreira (in mem.). ISSN 1982-7636. pp. 362-383

www.redp.uerj.br

unconstitutional regarding those companies with affiliations located outside of those jurisdictions.

It is worth highlighting that in the concept of income in the Brazilian Constitution there is no clear reference to where the income is generated. It is a question to be solved by the legislator. Despite this fact, the STF gives predominance to the purpose of the rule (tackling tax avoidance) using the place from which income would come as a parameter to examine the constitutionality of the rule, the facts that show the trend of the court to favouring a policy argument (especially those preferred by the legislator) when the constitutional parameter is unclear.

These two elements of the Brazilian Supreme Court's legal reasoning is a sound signal that the Court will give major deference to the Executive and Legislative to solve the case of tax avoidance. Considering the failed experience with provisional measures $n^{\circ} 66$ and 685, that make clear the scale and the complexity of the task to be solved, perhaps the STF should recognize the fact that the solution of tax avoidance scheme must be resolved before the concrete case.

\section{CONCLUSION}

The Brazilian tax planning debate, as in other countries of the world, is polarized and it is unclear what the next developments will be. As seen above, among the academic authors and the executive and legislative branches, there is no consensus about what characterizes legitimate and abusive tax planning. The legislative efforts to regulate tax planning have not succeeded.

This scenario open space to the Constitutional Court to manage the tax law through the constitutional jurisdiction that requires the use of new forms of legal reasoning to deal with new concepts and unlike questions raised. This fact is not a beacon of dysfunction of the classic principle of division of power or inefficiency of the legislative and executive branches. It is a signal of a necessary evolution of legal reasoning in the constitutional process to handle the increasing complexity of international tax law that changes faster than never.

The changes in the legislative and the executive branch's decision-making process, which interact even more with international regulations and cannot be focused only 
Revista Eletrônica de Direito Processual - REDP.

Rio de Janeiro. Ano 13. Volume 20. Número 1. Janeiro a Abril de 2019

Periódico Quadrimestral da Pós-Graduação Stricto Sensu em Direito Processual da UERJ

Patrono: José Carlos Barbosa Moreira (in mem.). ISSN 1982-7636. pp. 362-383

www.redp.uerj.br

in national perspectives, must be accompanied of change in the judiciary branch's legal reasoning. It means that the constitutional courts must identify those changes and evaluate them critically and carefully without forgetting the complex scenario in which that they are taken. Inverse to a competition among the branches of state's power, this is a process of constitutional cooperation and dialogue among them.

Naturally, this innovative form of legal reasoning demands a distinct approach to thinking about legal issues, especially concerning international tax law, what demands the opening of new theoretical and empirical research fronts. As the quote attributed to Albert Einstein affirms "you can never fix a problem using the same mindset used when the problem was created." This observation applies to the new challenges in the tax law and constitutional jurisdiction.

\section{BIBLIOGRAPHY}

ABRAHAM, Marcus. Curso de Direito Tributário Brasileiro, $1^{\mathrm{a}}$ ed., Rio de Janeiro: Forense, 2018.

A Segurança Jurídica e os Princípios da Legalidade e da Tipicidade Aberta in: RIBEIRO, Ricardo Lodi; RIBEIRO, Ricardo Lodi; ROCHA, Sergio André (Orgs.). Legalidade e tipicidade no Direito Tributário. São Paulo: Quartier Latin, 2008.

O Planejamento Tributário e o Direito Privado, $1^{\text {a }}$ ed., Rio de Janeiro: Quartier Latin, 2007.

Os 10 anos da Norma Geral Antielisiva e as Cláusulas do Propósito

Negocial e da Substância sobre a Forma Presentes no Direito Brasileiro. Revista

Dialética de Direito Tributário, Rio de Janero, n. 80, 2011.

BRASIL. Lei Complementar $n^{\circ}$. 104, de 10 de janeiro de 2001. Diário Oficial [da]

República Federativa do Brasil. Poder Executivo, Brasilia, DF, 11 jan. 2001, Seção

1, p. 1 . 
Revista Eletrônica de Direito Processual - REDP.

Rio de Janeiro. Ano 13. Volume 20. Número 1. Janeiro a Abril de 2019

Periódico Quadrimestral da Pós-Graduação Stricto Sensu em Direito Processual da UERJ

Patrono: José Carlos Barbosa Moreira (in mem.). ISSN 1982-7636. pp. 362-383

www.redp.uerj.br

BRASIL. Lei Ordinária nº. 8.981, de 20 de janeiro de 1995. Diário Oficial [da] República

Federativa do Brasil. Poder Executivo, Brasilia, DF, 23 jan. 1995, Seção 1, p. 857.

BRASIL. Lei Ordinária nº 9.311, de 24 de outubro de 2001. Diário Oficial [da] República

Federativa do Brasil. Poder Executivo, Brasilia, DF, 25 out. 1996, Seção 1, p. 21877.

BRASIL. Medida Provisória nº. 2.158-35, de 24 de agosto de 2001. Diário Oficial [da]

República Federativa do Brasil. Poder Executivo, Brasilia, DF, 27 ago. 2001, Seção

1, p. 26.

BRASIL. Medida Provisória nº . 66, de 29 de agosto de 2002. Diário Oficial [da] República

Federativa do Brasil. Poder Executivo, Brasilia, DF, 30 ago. 2002, Seção 1, p. 1.

BRASIL. Supremo Tribunal Federal. $n^{\circ}$. 66, de 29 de agosto de 2002. Diário Oficial [da]

República Federativa do Brasil. Poder Executivo, Brasilia, DF, 30 ago. 2002, Seção 1 , p. 1.

CANOtilho, J.J Gomes; MOREIRA, Vital. Direito Constitucional e Teoria da Constituição, $7^{\text {a }}$ ed., Coimbra: Livraria Almedina. 2004.

CARRAZZA, Roque Antonio. Curso de Direito Constitucional Tributário, $2^{a}$ ed., São Paulo: Malheiros, 2017.

COÊLHO, Sacha Calmon Navarro Coêlho. Curso de Direito Tributário Brasileiro, $15^{\text {a }}$ ed., São Paulo: Forense, 2017.

DUFF, David G. Tax Avoidance in the 21st Century. Australian Business Tax Reform

$\begin{array}{lllll}\text { Retrospect } & \text { and } & \text { Prospect, } & \text { Disponível }\end{array}$ $<$ https://ssrn.com/abstract=1457453>. Acesso em: 12 jul. 2018.

FREEDMAN, Judith. Designing a General Anti-Abuse Rule: Striking a Balance. Asia-

Pacific Tax Bulletin, ago. 2014. Disponível em <https://papers.ssrn.com/sol3/papers.cfm?abstract_id=2488541> Acesso em: 12 jul 2018 .

GARNER, Brian A. (Org.). Black's Law Dictionary, $8^{\text {a }}$ ed., London: Thomson West, 2004.

GOMES, Marcus Lívio. A Interpretação da Legislação Tributária, $1^{a}$ ed., Rio de Janeiro: Quartier Latin, 2010.

GRECO, Marco Aurélio Grego. Planejamento tributário, $3^{\text {a }}$ ed., São Paulo: Dialética, 2008. 
Revista Eletrônica de Direito Processual - REDP.

Rio de Janeiro. Ano 13. Volume 20. Número 1. Janeiro a Abril de 2019

Periódico Quadrimestral da Pós-Graduação Stricto Sensu em Direito Processual da UERJ

Patrono: José Carlos Barbosa Moreira (in mem.). ISSN 1982-7636. pp. 362-383

www.redp.uerj.br

GREGGI, Marco, Avoidance and Abus De Droit: The European Approach. Tax Law

eJournal of Tax Research, 2008. Disponivel em: <https://ssrn.com/abstract=1153166>. Acesso em: 12 jul 2018.

MACHADO, Hugo de Brito. Os Princípios Jurídicos da Tributação na Constituição de 1988, $5^{\text {a }}$ ed., São Paulo: Dialética, 2004.

MARTINS, Ives Gandra. Teoria da Imposição Tributária. São Paulo: LTr, 1988.

NABAIS, José Casalta. O Dever Fundamental de Pagar Impostos. $1^{a}$ ed., Coimbra: Livraria Almedina. 2004.

OCDE, Mandatory Disclosure Rule, Action 12 - 2015 - Final Report, 2015, Disponível em $<$ https://read.oecd-ilibrary.org/taxation/mandatory-disclosure-rules-action-12-2015final-report_9789264241442-en\#page2>. Acesso em 8 jul. 2018.

OCDE. Public Disclosure Draft. Beps Action 12: Mandatory Disclosure Rule, 2015.

Disponível em <http://www.oecd.org/tax/aggressive/discussion-draft-action-12mandatory-disclosure-rules.pdf.>

Acesso em 8 jul. 2018.

ROCHA, Sérgio André. Da Lei à Decisão, $1^{a}$ ed., Rio de Janeiro: Lumen Juris, 2017.

SUPREME COURT OF UNITED STATES. Gregory v. Helvering, 293 U.S. 465 (1935).

Argued December 4, 5, 1934. Decided January 7, 1935. Disponível em < https://supreme.justia.com/cases/federal/us/293/465/>, Acesso em 5 out 2018.

TORRES, Ricardo Lobo. Normas de Interpretação e Integração do Direito Tributário, $4^{\mathrm{a}}$ ed., Rio de Janeiro: Renovar, 2006.

Tratado de Direito Constitucional Financeiro e Tributário, $3^{\mathrm{a}}$

ed., Rio de Janeiro: Renovar, 2014.

Planejamento Tributário: elisão abusiva e evasão fiscal. São

Paulo: Elsevier, 2013.

TÔRRES, Heleno Taveira. Direito tributário e direito privado: autonomia privada, simulação e elusão tributária, v.1, 1ª ed., São Paulo: RT, 2003.

WAERZEGGERS, Christophe; HILLIER, Cory. Introducing a general anti-avoidance rule (GAAR) - Ensuring that a GAAR achieves its purpose. Tax Law IMF Technical Note 2016/1, 2016.2 Disponível em: $<$ https://www.imf.org/external/pubs/ft/tttn/2016/tttn1601.pdf>. Acesso em: 12 jul. 2018. 
Revista Eletrônica de Direito Processual - REDP.

Rio de Janeiro. Ano 13. Volume 20. Número 1. Janeiro a Abril de 2019

Periódico Quadrimestral da Pós-Graduação Stricto Sensu em Direito Processual da UERJ

Patrono: José Carlos Barbosa Moreira (in mem.). ISSN 1982-7636. pp. 362-383

www.redp.uerj.br

WEISBACH, David A. Corporate Tax Avoidance. University of Chicago Law \&

Economics, Olin Working Paper, n. 202. Disponível em:

<https://ssrn.com/abstract=487103> Acesso em: 25 jul._2018.

XAVIER, Alberto, Tipicidade da Tributação, Simulação e Norma Geral Antielisiva. São

Paulo: Dialética, 2001. 